\title{
Circular economy indicators in relation to eco-innovation in European regions
}

\author{
Marzena Smol $^{1}$ - Joanna Kulczycka ${ }^{2}$ Anna Avdiushchenko ${ }^{3,4}$
}

Received: 28 April 2016/ Accepted: 25 December 2016/Published online: 4 January 2017

(C) The Author(s) 2017. This article is published with open access at Springerlink.com

\begin{abstract}
The concept of a circular economy (CE) has become popular and important issue in environmental management in recent years; however, there are not particular indicators dedicated to it in regional policy. CE approach is an industrial system that is restorative by design, and it emphasises that it is important that, rather than extracting natural resources, the materials that have already been taken can and should be recovered and reused in different ways, thereby securing natural resources from over-exploitation. In order to meet CE assumptions, modern and innovative technologies that allow for the recovery of valuable materials should be developed. This also applies to eco-innovation that connects technology development with environmental aspects. It is therefore obvious that issues of $\mathrm{CE}$ and eco-innovation are linked, and a uniform methodology aimed at compare the levels of moving to CE including eco-innovation solutions should be established. Because the focus in European Union (EU) has been paid on regions, measuring of $\mathrm{CE}$-eco-innovations levels is especially important at the regional level. In this paper, the proposals of CE indicators, based on eco-innovation factors, which can be possible to create based on existing data set (Eurostat, Cohesion policy) are presented. It is recommend to use of five group indicators for measuring regional CE-eco-innovation. Based on Eco-
\end{abstract}

Marzena Smol

smol@meeri.pl; smol@min-pan.krakow.pl

1 Mineral and Energy Economy Research Institute of the Polish Academy of Sciences, Wybickiego 7, 31-261 Cracow, Poland

2 AGH University of Science and Technology, Cracow, Poland

3 Jagiellonian University, Cracow, Poland

4 Faculty of Management, National Mining University, Dnipropetrovks, Ukraine
Innovation Scoreboard which describes innovation measurement, three of proposed indicator groups are associated directly with innovations, taking into account the principles of CE: CE-eco-innovation inputs, CE-eco-innovation activities and CE-eco-innovation outputs, and other two groups of indicators are effects of the CE-eco-innovation introduction: resource efficiency outcomes and socio-economic outcomes. This way of measuring CE-eco-innovation allows for create holistic, systematic and integrated approach for the CE concept at the regional level. Proposed indicators can be used in current transition stage for assessment of implementation regional policy and as a base for creation final CE indicators.

Keywords Circular economy · Eco-innovation - Regional policy $\cdot$ Sustainability indicator $\cdot$ Waste reduction

\section{Introduction}

Nowadays one of the most significant challenges in environmental management across the world is ensuring that our activities conform to the principles of sustainable development (SD) (Xu et al. 2014) which balances three requirements: the social, economic and environmental objective (Krajnc and Glavič 2003). The concept of sustainability was often critical for businesses and individuals to understand and apply (Helling 2015) due to as a main drivers for sustainable economic growth technical progress (Valipour 2015b) and innovation were indicated (Gassmann 2006). An increase in Europe's innovative potential and competitiveness (Thomé et al. 2016) was a central objective of the European Union (EU) Sustainable Consumption and Production (SCP) and Sustainable Industrial Policy (SIP) Action Plan (EC2008) for Europe (Buttol et al. 
2012). The enterprises systematically started to apply improvement tools aimed at: production processes, management practices (Valipour et al. 2015), products and communication with internal and external stakeholders (Staniškis et al. 2012). This has led to the common introduction of innovation in business operations (Bossink 2015). Subsequently, a special attention was started to pay for environmental considerations which must be integrated into the corporate culture and business planning at all levels of design, manufacturing, distribution and disposal (Krajnc and Glavič 2003). The concept of eco-innovation was introduced to EU regulations aimed at promoting ecosolutions (Buttol et al. 2012).

Currently, a newest concept for the pursuit of global sustainability (Staniškis 2012) is a circular economy (CE) strategy (Lilja 2015). The most important benefit in moving to a more CE-based approach is the possibility of retaining the added value in products for as long as possible ( $\mathrm{Smol}$ et al. 2015), extracting their maximum value and eliminating waste. CE-based systems keep resources within the economy (Valipour 2015a). When a product has reached the end of its life, products can be efficiently reused again and again and create further value (COM 2014, 398). One of the factors determining the possibility of moving towards a $\mathrm{CE}$ is the implementation of innovation technologies (Wdowin et al. 2014), with a particular emphasis on eco-innovation. Despite the fact that these two issues are linked, a uniform methodology designed to compare the degree to which economies have moved towards a $\mathrm{CE}$ which also includes eco-innovation has not currently been established. Therefore, the objective of this study was to propose indicators for integrated assessment of CE-ecoinnovation. Because EU has focused on the regions in the last few years (Seppäläa et al. 2005), the measuring of the level of CE-eco-innovation is especially important at the regional scale. EU regional policy lays emphasis on the importance of regions. This is closely related to the guidelines of structural policy, which provide the framework for establishing regional and interregional conditions for the modernisation of the economic structure in order to implement, maintain and increase the potential competitiveness of the region. In the available literature, EU regional policy is identified as one of the main pillars of sustainable development (Seppäläa et al. 2005). Therefore, the development and promotion of regional competitiveness and CE-eco-innovation have become a central issue.

In this study, proposals for indicators are presented based on the currently existing eco-innovation indicators used in the Eco-Innovation Scoreboard. For this moment, the database about eco-innovation are available, but there is no database about $\mathrm{CE}$ items in regional development, so eco-innovation database should be extended and used for the assessment of regional development related to $\mathrm{CE}$.
Based on the proposed indicators, it is possible to assess whether a given region (but also a country) is promoting eco-innovation and maintaining the principle of $\mathrm{CE}$ and they illustrate possible ways of measuring changes in regional CE-eco-innovations.

\section{Development of the concept of the circular economy (CE)}

The circular economy is a relatively new concept, although the idea behind the CE has existed for a long time (Murray et al. 2015). As early as 1848, Hofman, the first President of the Royal Society of Chemistry, stated "...in an ideal chemical factory there is, strictly speaking, no waste but only products. The better a real factory makes use of its waste, the closer it gets to its ideal, the bigger is the profit" (Lancaster 2002). The CE model is actually the opposite of a linear one and is based on closed-loops like a biological life cycle. It was not widely debated in the academic and scientific literature on sustainability (Pitt and Heinemeyer 2015), but it has become more popular with recent research (Stahel 2015). In total $€ 650$ million will come from Horizon 2020, the EU funding programme for research and innovation, and $€ 5.5$ billion from structural funds for waste management and investments in the $\mathrm{CE}$ at national level. The Investment Plan for Europe (http:// ec.europa.eu) will also play an important role in this context (European Commision Horizon 2020 2016).

In the twentieth century, the "preventive approach" has been replaced with the "restorative approach" both in Europe and across the whole world. The way of thinking in the twenty-first century has started to be more global, holistic and systematic. Society and government have begun to introduce one more element- "restore"-into the "reduce-recycle-reuse concept". The CE model is based on concepts such as "cradle-to cradle TM", where industry, by being waste-free, operates with no impact upon the environment (McDonough and Braungart 2002).

The term "closed economy" was first used in 1966 (Boulding 1966). The concept was later developed by (Stahel and Reday-Mulvey 1976), and it influenced German (Bilitewski 2007) and Japanese policy in the 1980s and 1990s (Moriguchi 2007). These policies, in turn, also inspired China to install the $\mathrm{CE}$ as its major framework for the delivery of increased growth but with decreased environmental damage. This is reflected in the "Circular Economy Promotion Law" (2009) and in the 11th and 12th "5 Year Plans" in China.

From a practical point of view, the CE approach is vital because in the twenty-first century science is currently looking for effective restorative approaches to give future generations the possibility of more sustainable development. Turning waste into a resource is one key to a CE. 
European experience of the implementation of a $\mathrm{CE}$ shows that this concept started to transcend into policy making in Europe in 2008 with Directive 2008/98/EC (Official Journal of the European Union 2008) on waste and further in the Europe 2020 Strategy for smart, sustainable and inclusive growth for 2014-2020. The EU's next step was made by the European Parliament in December 2014. It adopted the communication from the European Commission, "Towards a Circular Economy: a Zero Waste Programme for Europe" (COM 2014, 398). This document emphasised the necessity of involving ecoinnovation in order to, inter alia, boost recycling and prevent the loss of valuable materials; create jobs and economic growth; show how new business models can emerge; move us towards zero waste through eco-design and industrial symbiosis; and reduce greenhouse emissions and environmental impacts (Koellner et al. 2007). On 2 December 2015, the European Commission put forward a package to support the EU's transition to a circular economy (COM 2015, 614). The package is composed of a set of both general and material-specific actions. While some obstacles to a $\mathrm{CE}$ are generic, different sectors and materials face specific challenges due to the particularities of the value chain, and it is correlated to eco-innovation.

As for the development of the CE approach at the nongovernmental level, the experience of the UK should be mentioned. A leading follower of the CE in the UK is the Ellen MacArthur Foundation, an NGO, which has produced reports on the concept (Towards the Circular Economy 2012, 2013, 2014). The reports examine the potential of the $\mathrm{CE}$ as a new concept for development. The Foundation is very active and for the time being they already have obtained support for global innovation. Companies implementing the concept include Philips, Renault, Google, Unilever, Cisco and Kingfisher.

As far as NGO interest in the CE is concerned, fairly similar processes are under way in France, the Netherlands and in other European countries. It shows that interest in this concept is growing.

Some examples of the implementation of a CE approach at legislative level already exist (China, Japan, Germany, the UK, EU level), but there are still some tensions and limitations inherent in its adoption and application at different levels, i.e. still not developed on regional level.

At the same time, existing CE approaches are valuable and have a tendency to develop further. They are strongly focused on resource efficient production. This can be proved by the main principles of the concept presented in the analytical report "Towards a Circular Economy: Business Rationale for an Accelerated Transition" (Towards the Circular Economy 2015):
- Principle 1: Preserve and enhance natural capital by controlling finite stocks and balancing renewable resource flows.

- Principle 2: Optimise resource yields by circulating products, components and materials at the highest utility at all times in both technical and biological cycles.

- Principle 3: Foster system effectiveness by revealing and designing out negative externalities.

It can be observed that an innovative approach is in fact needed for each aspect of the CE concept. All strategic EU documents on the circular economy and the reports presented above see innovation as the heart of any transition to a CE. It is also obvious that a special role should be given to eco-innovations and that they should be a key driver, because the $\mathrm{CE}$ concept is all about economic growth, creating jobs, and at the same time reducing environmental impacts, including carbon emissions.

\section{The relationship between the circular economy (CE) and eco-innovation}

As noted above, in recent years issues related to environmental protection have been taken into account by society, investors and government (García-Pozo et al. 2016) as a factor in their purchasing decisions (Garrido-Baserba et al. 2016). This applies in particular to business investment in every branch of industry. The consequence of this is a simultaneous striving by many firms to achieve superior environmental and economic performance (Del Río et al. 2010) through the adoption of the idea of environmental innovation, also known as eco-innovation (Scarpellini et al. 2012).

The strategy of eco-innovation is recent and therefore is under a continual process of development and review (Buttol et al. 2012). The definition of eco-innovation is very broad-ranging. One of the widely known definitions of eco-innovation is as follows "it is the production, assimilation or exploitation of a product, production process, service or management or business method that is novel to the organisation (developing or adopting it) and which results, throughout its life cycle, in a reduction of environmental risk, pollution and other negative impacts on resources used (including energy use) compared to the relevant alternatives" (Kemp and Pearson 2008). In the Eco-Innovation Observatory (EIO), eco-innovation is defined as the "introduction of any new or significantly improved product (good or service), process, organisational change or marketing solution that reduces the use of natural resources (including materials, energy, water and 


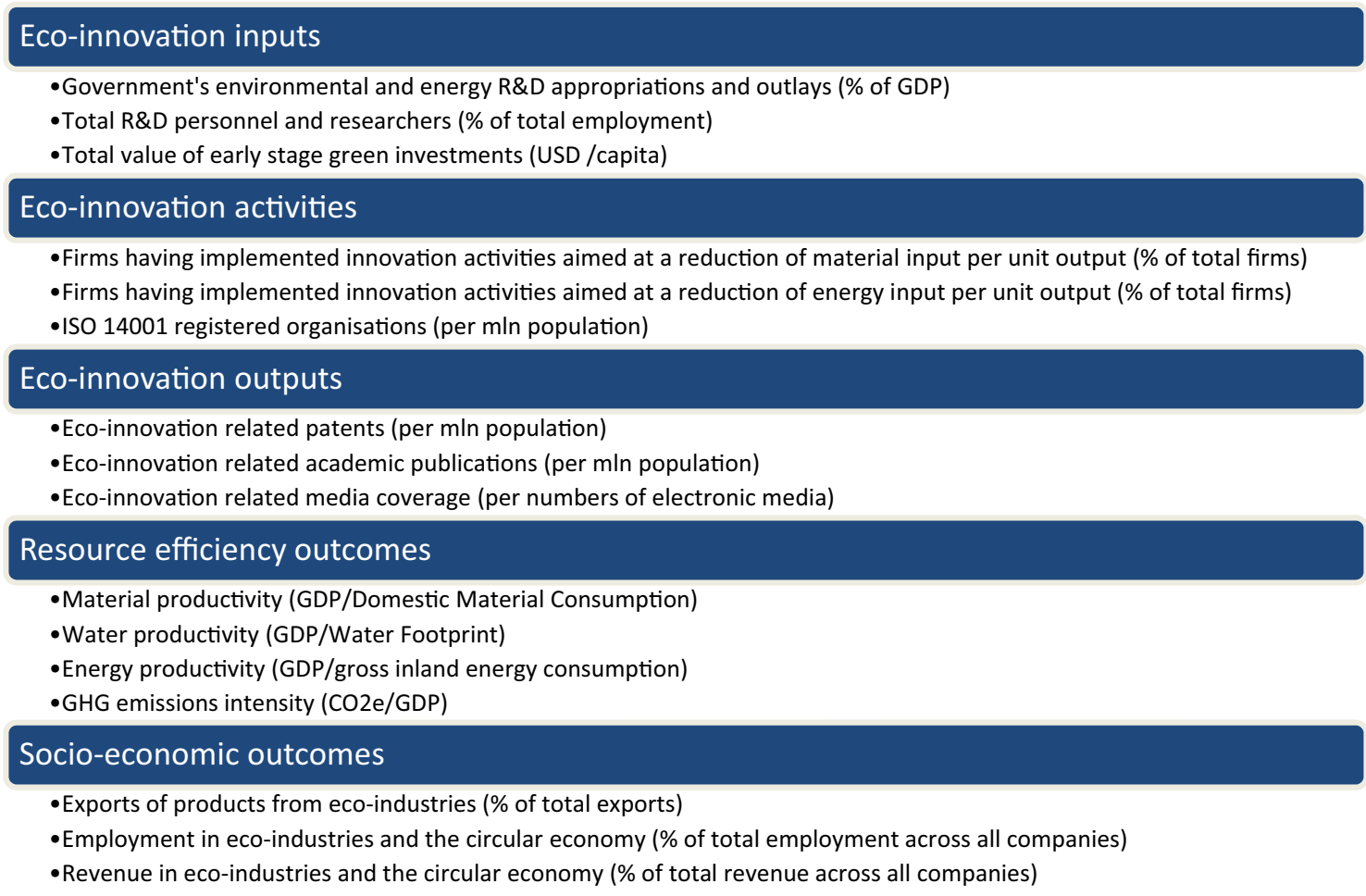

Fig. 1 Eco-innovations indicators used in the Eco-Innovation Scoreboard. Source The Eco-Innovation Scoreboard 2013

land) and decreases the release of harmful substances across the whole life-cycle" (EIO 2012). In general, ecoinnovations are a special kind of innovation that contribute to creating new solutions that provide added value to consumers and businesses (Makara et al. 2016) by significantly reducing their impact on the environment, which is the basic feature distinguishing them from other types of innovation.

It should be emphasised that the allocation of eco-innovation is multidimensional and its characteristics can also be made to take into account, among other factors, the range of eco-innovation in the context of the life cycle, scale and complexity of implementing eco-innovation and the complexity of developing methods for eco-innovation (Urbaniec and Gerstlberger 2011).

The importance of undertaking eco-innovation was emphasised in the basic EU strategy for further development "Europe 2020: Strategy for smart, sustainable and inclusive growth for 2014-2020" and in one of its 7 flagship initiatives the "Innovation Union". The "Europe 2020" strategy is focused on five ambitious goals in the areas of employment, innovation, education, poverty reduction and climate/energy. As a consequence of this, many of the activities at EU level are concentrated on ecoinnovation. The planned EU transition to a $\mathrm{CE}$ is fostering eco-innovation development at the macro-, meso- and micro-levels. So, it is advisable to look at eco-innovation through the prism of the circular economy perspective.

\section{Measuring eco-innovation}

Interestingly, a large amount of work has been carried out on systems approaches to innovation (Kemp 2011) and associated methods of measuring innovation have been analysed and described (Spiers et al. 2008). Currently, more and more studies have also discussed the measurement of eco-innovation. However, measuring eco-innovation in national economies or regions is even more difficult than measuring their overall innovation. This is a result of the difficulty inherent in determining the scope of the audit and a method of measuring the effects of the introduction of innovative environmental solutions. This is a new area of research in international statistics which is currently being developed by, among other bodies, the Organisation for Economic Co-operation and Development (OECD) and the European Union (EU). In the EU, research on ecoinnovation is conducted by the Eco-Innovation Observatory (EIO). One of the main tasks of the EIO is to collect data related to eco-innovation in European Union countries. On the basis of these indicators, a scoreboard of EcoInnovation ranking has been created. The index takes into account five groups of indicators. Three of them are directly related to eco-innovation: eco-innovation inputs, eco-innovation activities and eco-innovation outputs, and two of them are the effects of introducing eco-innovation: environmental resource efficiency outcomes and socioeconomic outcomes (Kowalska 2014). An overview of the 
indicators used in the 2013 version of the Eco-Innovation Scoreboard is shown in Fig. 1.

Currently, the index value in each of the five areas is calculated by the unweighted mean of the underlying indicators. Consequently each indicator has the same weighting in the five areas. The overall scoreboard of an EU Member State is calculated by the unweighted mean of the 16 sub-indicators in order to avoid bias by areas of the scoreboard which consist of only a few indicators. Based on the indicators presented, it is possible to assess whether a given country/region/company is eco-innovative. However, at a time when the CE concept is evolving, it is also important to consider the actions of individual institutions with regard to the sustainable management of raw materials (Kulczycka et al. 2016) on the basis of a "zero-waste" strategy. For now, the lack of basic research into the CE concept has caused delays in its further development and practical application. Moreover, the issues of the interrelationship between the CE concept and levels of eco-innovation and the sustainability of regions have not yet been investigated. Therefore, actions should be taken which are directed at identifying new indicators thanks to which it will be possible to assess whether a region is eco-innovative while maintaining the principles of a circular economy. This should be prepared on a regional basis as regions, in most cases, are the driving force of a country's prosperity. This level is also good because it gives us the opportunity to combine interest from the micro- and macro-level, taking into account all the stakeholders involved.

Based on preliminary research, it has been shown that there have been many attempts to estimate regional development (Caschili et al. 2015), but none of these has used an approach based on the concept of a circular economy although there are some works devoted to a region's eco-efficiency using life-cycle assessment (LCA), material flow analysis (MFA) and/or data envelopment analysis (DEA) (Hammer et al. 2003). Sastre et al. (2015) analysed potential contributions of regional material flow (patterns of material extraction, trade, consumption and productivity) accounting to the characterisation of environmental pressures within the 1996-2010 period. The authors indicated that an interregional trade is a significant source of environmental pressure (Sastre et al. 2015). In Sleeswijk (2011) work, LCA was used as a tool for evaluation of regional differentiation in a global perspective (Sleeswijk 2011). It has to be mentioned that environmental sustainability of a region is affected by composition of the various factors and it could be a crucial concern for planners and policy-makers (Lou et al. 2015). But that research neither contains a $\mathrm{CE}$ approach nor does it connect such an approach with sustainability and eco-innovation at a regional level. In spite of this fact, measurement of ecoinnovation, taking into account $\mathrm{CE}$ principles, will allow for an easier and more conscious (in terms of resources) comparison of the development of individual regions. LCA analysis (Kulczycka and Smol 2015) could be an effective tool for environmental assessment appropriate to the regional level (Generowicz et al. 2015). Such an approach was actually defined by the European Commission as the basic strategy for measuring the eco-effectiveness of a project or organisation, so it should be adaptable to a regional $\mathrm{CE}$ dimension.

\section{A conceptual framework for measuring the circular economy (CE)}

It should be emphasised that improved waste management in accordance with the model of a CE helps not only to reduce health and environmental problems, but also to create availability of metals, and other resources from reuse and recycling. According to information provided by a campaign run by the European Environmental BureauMake Resources Count, the average European consumes 16 tonnes of materials every year, of which 6 tonnes become waste and $64 \%$ of that waste is landfilled or burnt. This means that the potential for reuse is lost (makeresourcescount.eu). Moreover, global demand for resources is increasing every year, but the world's resources are limited. In 2014, EU presented a new list of critical raw materials. Twenty raw materials were identified as critical from the list of fifty-four candidate materials: antimony, beryllium, borates, chromium, cobalt, coking coal, fluorspar, gallium, germanium, indium, magnesite, magnesium, natural graphite, niobium, Platinum Group Metals (PGMs), phosphate rock, heavy Rare Earth Elements (REEs), light REEs, silicon metal and tungsten (COM 2014, 297). These materials are critical due to the risks of a shortage of supply and the fact that the impact of a shortage of supply on the economy is greater than those of most other raw materials. Therefore, the development of a sustainable method for recycling and conserving the raw materials used in society is required (Lederer et al. 2014) and that is why a move to a circular economy concept is needed. This actually represents a development strategy that entails economic growth without increasing the consumption of resources, profoundly transforms production chains and consumption habits, and redesigns industrial systems at system level. It relies on technological, social and organisational eco-innovations. However, there is no recognised method for assessing how effectively the product or the whole company makes the transition from a linear mode of operation to a circular model, and there are no tools to support such measurements.

A methodology and tools which can be used to assess how well a product/company performs in the context of the 
$\mathrm{CE}$ are proposed in the Circularity Indicators Project $(\mathrm{CI})$. The methodology presented allows companies to estimate how advanced they are on their journey from a linear to a circular model. In order to ensure the robustness and relevance of the measurement system developed, leading European businesses who had provided product data to test, and other stakeholders including universities and investors who worked with the project team to develop, test and refine the system, were included during the preparation of the methodology. The proposed indicators in CIP refer exclusively to technical cycles and materials from nonrenewable sources as their circularity strategies and associated business benefits are better understood. One of the most important benefits is that such indicators can be used as a decision-making tool for designers, but might also be used for several other purposes including internal reporting, procurement decisions, and the rating or evaluation of companies. In CIP, the following indices are proposed: a main indicator, the Material Circularity Indicator, measuring how restorative the material flows of a product or company are, and complementary indicators that allow additional impacts and risks to be taken into account (CI 2015). The proposed indicators are very complex and detailed, which may in some cases discourage potential entrepreneurs from reporting their activities relating to resource management. Moreover, using a large number of environmental impact indicators could lead to difficulties in interpreting the meaning of each indicator in the CE implementation assessment. And what is also important that such methodology could not be used by regional authorities for measuring the effects of circular economy implementation. So, the indicators of CIP could not be used as instrument for support decision making as for implementation circular economy stimulation activities at the regional level.

\section{Measuring CE-eco-innovation in regional policy}

The proposals for CE indicators for regional policy including eco-innovation factors are presented in this work. The key point underlying the proposed indicators is the concept of a "circular economy" and its interrelationship with eco-innovation, with particular emphasis on the development of regions. The proposed indicators are prepared on the basis of the indicators directly related to ecoinnovation used in the Eco-Innovation Scoreboard (Fig. 1). They have been extended using issues related to resource efficiency and presented in Fig. 2. This approach to the collection of information on CE is relatively easy due to

\section{CE-Eco-innovation inputs \\ - Regional authorities environmental and energy R\&D for CE appropriations and outlays (\% of GDP) \\ -Regioanl total value of green early stage investments (EURO per capita) \\ CE-Eco-innovation activities \\ - Firms having implemented CE-eco-innovation activities aiming at a reduction of material input per unit output (\% of total firms in region) \\ - Firms having implemented CE-eco-innovation activities aiming at a increase of material recycling (\% of total firms in region)}

\section{CE-Eco-innovation outputs}

- Generated industrial waste (amount of waste/ person)

- Generated municipal waste (amount of waste/ person)

- Recycled industrial waste (amount of waste/ person)

- Recycled municipal waste (amount of waste/ person)

- Life cycle assessment of enterprises activity (amount companies with LCA reports per regions)

-Number of companies with "zero waste" program

\section{Resource efficiency out comes}

-Material productivity (regional GDP/Domestic Material Consumption of region)

-Water productivity (regional GDP/Water Footprint of region)

- Energy productivity (regional GDP/gross inland energy consumption of region)

- GHG emissions intensity (CO2e/regional GDP)

\section{Socio-economic outcomes}

-Employment in eco-industries and circular economy (\% of total employment across all companies of region )

- Revenue in eco-industries and circular economy (\% of total revenue across all companies of region)

Fig. 2 Proposed CE-eco-innovation indicators 
the fact that there are now databases on the eco-innovation that could be expanded in the future. The lack of indicators and information by which to design strategic plans to introduce CE-eco-innovation measures has not been considered a limitation (García-Pozo et al. 2016). Therefore, the $\mathrm{CE}$ indicators for regions are based on following assumptions:

1. The CE indicator should be created based on information from existing database.

2. They should be correlated with eco-innovation and regional policy indicators, i.e. including also the economic and social effect.

3. If it is possible, the indicators should measure the obtained results taking into account the whole life cycle of product or organisation.

4. They should cover the main assumption of EC, i.e. reflect the main levels of its development: (1) regenerate (renewable energy and raw materials), (2) share and optimise (prevention, waste reduction) and (3) loop (improved recycling technologies, digitalise) and exchange (breakthrough technologies) (EC Horizon 2020).

5. They should be a base for creation final CE indicators.

It should be mentioned that during the preparation of CE-eco-innovation indicators, not only waste is important issue. The environmental assessment (including LCA) and a new approach to customer support based on the service (lending of, renting, etc.) are essential, and therefore, they have been included and highlighted in the proposed indicators.

Due to the fact that there is no single overall indicator for innovation, it is recommended that five group indicators be used for measuring regional CE-eco-innovation. In a similar manner to the measurement of innovation, three of these are associated directly with innovation taking the principles of CE into account. The other two groups of indicators are related to the effects of the introduction of CE-eco-innovation-both environmental and socio-economic.

CE-eco-innovation inputs now include contribution of regional authorities into research and development (R\&D) related to CE. Currently, it is of common acceptance that, for the society progress, $R \& D$ is of paramount importance (Scarpellini et al. 2012). The EU countries regions have their own strategies for innovation development, which are called "intelligent directions for development". So, local authorities can influence directly in R\&D activities needed for particular region when they redistributing financial sources for innovations development. Appropriations and outlays into R\&D for $\mathrm{CE}$ should be measured and also regional total value for of green early-stage investments.

Further step is CE-eco-innovation activities measurement. In this point, activities directly related to reduction of material input and increase of material recycling and based not only in eco-innovations, but also on circular economy approach main principles should be taken into account.

In the CE-eco-innovation outputs, it is important to report the amount of both generated industrial and municipal waste. Moreover, as CE assumptions are closely related to the recovery of materials from waste, it is necessary to report the amount of industrial and municipal recycled waste. It should be highlighted that without measurement of these indicators, it is not possible to assess whether the regions implement eco-innovative activities according the principles of the CE. As for CE-eco-innovation output, it is reasonable to introduce the indicator related to LCA assessment, because as it was mentioned above, LCA was defined by the European Commission as the basic strategy for measuring eco-effectives of project and organisation (Helling 2015). It would be reasonable to integrate these criteria into measuring system for regional CE-eco-innovation dimension. It is proposed to measure output by amount companies with LCA reports per regions. During the integrated assessment of CE-eco-innovation of regions, it should be taken into account that many companies in order to achieve greater competitiveness and sustainability often are seeking synergies among themselves for network activities as sharing infrastructure and more efficient resource utilisation through complementarity of needs (Varbanov and Seferlis 2014). An important advantage of LCA method is the possibility for substitution different materials and products, e.g. raw material could be substituted by waste. It means that waste from one stakeholder could become a useful component for another player and is taken into account in LCA analysis. Currently, LCA method enables the most comprehensive identification, documentation and quantification of potential impacts on the environment (Kulczycka and Smol 2015). Moreover, for assessment of CE-eco-innovation, number of companies with "zero waste" programme should be also reported.

Moving to recourse efficiency outcomes, it is proposed to base these criteria on the same measures as it was designed in Eco-Innovation Scoreboard. The indicators presented there actually cover all main direction as for resource efficiency assessment. The only difference is that regional amounts of materials/water/energy consumption $\mathrm{CO}_{2}$ production and for calculating indicators should be introduced.

And the last group of indicators is represented by socioeconomic outcomes. At the Eco-Innovation Scoreboard, circular economy issues were already taken into account, so here level of employment at the CE-eco-industries and level of their revenue in region is suggested to be measured.

The proposed indicators are focused on eco-innovation perspectives, because of the view that this aspect is the 
most essential and could create the possibility of preparing a holistic, systematic and integrated approach to the CE concept at the regional level. Moreover, the proposed indicators are universal, so they could be easily used for the assessment of different regions, with various economic and ecological conditions. The main results of the implementation of these indicators will be:

- the creation of a systematic approach to the regional $\mathrm{CE}$;

- design indicators for measuring the regional CE;

- an investigation into the interrelationship between the $\mathrm{CE}$ and eco-innovation in regions through a model which helps to combine these aspects.

It should be emphasised that regional policy, in fact, should play a key role in promoting the CE approach and cannot be ignored. For example, through regional policy, it is possible to encourage the producers and consumers in regions to make more sustainable choices based on the principle of $\mathrm{CE}$. This can have a significant economic, environmental and social effect on the whole region and should take into account the various modi operandi of regions and set up a groups of indicators (taking into account regional specificities) in order to measure the effects of $\mathrm{CE}$ and its influences on eco-innovation.

According to the "zero waste" strategy, moving to circular economic models promises a much brighter future for the regional economy. It would allow European regions to rise to current and future challenges of the global pressure on resources and rising insecurity of supply. Currently, the lack of available data and theoretical knowledge indicating the relationship between a $\mathrm{CE}$ and eco-innovation does not allow the competitiveness of regions in this field to be compared.

\section{Conclusions}

The uniform methodology designed to compare the degree to which economies have moved towards a $\mathrm{CE}$ which also includes eco-innovation has not currently been established. Therefore, the main objective of current study was to propose indicators for integrated assessment of CE-ecoinnovation in European regions. The measuring of the level of CE-eco-innovation is significant at the regional scale according to EU regional policy lays emphasis on the importance of regions in last years.

The paper has concentrated on highlighting the way of designing indicators for measuring CE-eco-innovations at the regional level. The main outcome of conducted research is in presenting indicators which could be used for various purposes in the way of transition to circular economy in regions.
The main advantages of the proposed system of CEeco-innovation indicators are following:

- it is possibility to extend system of measuring of ecoinnovations and combine it with circular economy principles;

- it is based on transparent and accessible indicators, so it could be used by various direct and indirect stakeholder involved into regional policy creation and implementation;

- it is simple and quick instrument for assessment the level of CE-eco-innovation at the regional level;

- it could be used as an instrument for decision making support in order to implement circular economy principles and solutions in regions;

- it can influence setting up priorities for R\&D regional strategies, programmes and projects formation;

- it gives opportunity for comparison the level of CEeco-innovation implementation within regions in the EU countries.

The integrated approach proposed in the paper could be identified as a holistic system of indicators for CE-ecoinnovation measuring.

Acknowledgements This study is supported by the Electra project (agreement number 2012-2738) that is financed by the Erasmus Mundus programme of the European Union and by Ministry of Science and Higher education of Poland (statutory research of Mineral and Energy Economy Research Institute of the Polish Academy of Sciences MEERI PAS and AGH University of Science and Technology).

Open Access This article is distributed under the terms of the Creative Commons Attribution 4.0 International License (http://crea tivecommons.org/licenses/by/4.0/), which permits unrestricted use, distribution, and reproduction in any medium, provided you give appropriate credit to the original author(s) and the source, provide a link to the Creative Commons license, and indicate if changes were made.

\section{References}

Bilitewski B (2007) Circular economy in Germany. In: Eleventh international waste management and landfill symposium, Cagliari, Italy, 1-5 Oct 2007

Bossink BA (2015) Demonstration projects for diffusion of clean technological innovation: a review. Clean Technol Environ Policy 17(6):1409-1427

Boulding KE (1966) The economics of the coming spaceship earth. In: Jarrett (ed) Environmental quality in a growing economy. Johns Hopkins Press, Baltimore

Buttol P, Buonamici R, Naldesi L, Rinaldi C, Zamagni A, Masoni P (2012) Integrating services and tools in an ICT platform to support eco-innovation in SMEs. Clean Technol Environ Policy 14(2):211-221

Caschili S, De Montis A, Trogu D (2015) Accessibility and reality indicators for regional development. Comput Environ Urban Syst 49:98-114 
Circularity Indicators (CI) An Approach to Measuring Circularity (2015) Project overview. ellen macarthur foundation and granta design. ellenmacarthurfoundation.org/programmes/insight/circularity-indicators. Accessed 26 May 2016

Commission of European Communities. Communication No. 297 (2014) On the review of the list of critical raw materials for the $\mathrm{EU}$ and the implementation of the Raw Materials Initiative. (COM 2014, 297)

Commission of European Communities. Communication No. 398 (2014) Towards a circular economy: a zero waste programme for Europe. (COM 2014, 398)

Commission of European Communities. Communication No. 614 (2015) Closing the loop-an EU action plan for the circular economy. (COM 2015, 614)

Del Río P, Carrillo-Hermosilla J, Könnölä (2010) Policy strategies to promote eco-innovation. J Ind Ecol 14(4):541-557

Directive 2008/98/EC of The European Parliament and of The Council of 19 November 2008 on Waste. (Official Journal of the European Union, 2008)

Eco-Innovation Observatory (EIO) (2012) Methodological Report. Eco-Innovation Observa-tory. Funded by the European Commission, DG, Environment, Brussels, Belgium

Eco-Innovation Scoreboard (2013), www.eco-innovation.eu/images/ stories/Eco-Innovation_Scoreboard_2013_Technical_Note.pdf. Accessed 24 Jan 2016

European Commision Horizon 2020 (EC Horizon 2020) (2016) Societal challenge 5 'climate action, environment, resource efficiency and raw materials' advisory group recommendations, programming period 2018-2020. Belgium, Brussels

García-Pozo A, Sánchez-Ollero JL, Ons-Cappa M (2016) ECOinnovation and economic crisis: a comparative analysis of environmental good practices and labour productivity in the Spanish hotel industry. J Clean Prod. doi:10.1016/j.jclepro.2016. 01.011

Garrido-Baserba M, Reif R, Molinos-Senante M, Larrea L, Castillo A, Verdaguer M, Poch M (2016) Application of a multi-criteria decision model to select of design choices for WWTPs. Clean Technol Environ Policy 18(4):1097-1109

Gassmann O (2006) Opening up the innovation process: towards an agenda. R\&D Manag 36(3):223-228

Generowicz A, Henclik A, Kulczycka J, Kowalski Z (2015) Evaluation of technology solutions for municipal waste incineration using LCA results and multi-criteria analysis. J Environ Account Manag 3:169-180

Hammer M, Giljum S, Bargigli S, Hinterberger F (2003) Material flow analysis on the regional level: questions, problems, solutions. Sustainable Europe Research Institute (SERI), Vienna

Helling R (2015) Driving innovation through life-cycle thinking. Clean Technol Environ Policy 17(7):1769-1779

Kemp R (2011) Innovation for sustainable development as a topic for environmental assessment. J Ind Ecol 15(5):673-675

Kemp R, Pearson P (2008) Final report MEI project about measuring eco-innovation: deliverable 15 of MEI project (D15), www.oecd. org/greengrowth/consumption-innovation/43960830.pdf. Accessed 20 Jan 2016

Koellner T, Suh S, Weber O, Moser C, Scholz RW (2007) Environmental impacts of conventional and sustainable investment funds compared using input-output life-cycle assessment. J Ind Ecol 11(3):41-60

Kowalska A (2014) Implementing eco-innovations. Determinants and effects. Ann Polish Assoc Agric Agribus Econ 16(3):153-158

Krajnc D, Glavič P (2003) Indicators of sustainable production. Clean Technol Environ Policy 5(3-4):279-288

Kulczycka J, Smol M (2015) Environmentally friendly pathways for the evaluation of investment projects using life cycle assessment
(LCA) and life cycle cost analysis (LCCA). Clean Technol Environ Policy 18(3):829-842

Kulczycka J, Kowalski Z, Smol M, Wirth H (2016) Evaluation of the recovery of Rare Earth Elements (REE) from phosphogypsum waste-case study of the WIZÓW chemical plant (Poland). J Clean Prod 113:345-354

Lancaster M (2002) Principles of sustainable and green chemistry. In: Clark J, Manqueary D (eds) Handbook of green chemistry and rechnology. Blackway Science. Ltd., OxfordLtd

Lederer J, Laner D, Fellner J (2014) A framework for the evaluation of anthropogenic resources: the case study of phosphorus stocks in Austria. J Clean Prod 84:368-381

Lilja RK (2015) Policy instruments for promoting material efficiency: case of Finland. Clean Technol Environ Policy 17(7):2029-2040

Lou B, Qiu Y, Ulgiati S (2015) Emergy-based indicators of regional environmental sustainability: a case study in Shanwei, Guangdong, China. Ecol Indic 57:514-524

Makara A, Smol, Kulczycka J, Kowalski Z (2016) Technological, environmental and economic assessment of sodium tripolyphosphate production-a case study. J Clean Prod 133:243-251

McDonough W, Braungart M (2002) Cradle to cradle: remaking the way we make things. North Point Press, New York

Moriguchi Y (2007) Material flow indicators to measure progress toward a sound material-cycle society. J Mater Cycles Waste Manag 9(2):112-120

Murray A, Skene K, Haynes K (2015) The circular economy: an interdisciplinary exploration of the concept and application in a global context. J Bus Eth. doi:10.1007/s10551-015-2693-2

Pitt J, Heinemeyer (2015) Introducing ideas of a circular economy. In: Stables K, Keirl S (eds) Environment, ethics and cultures: design and technology education's contribution to sustainable global futures. University of London, United Kingdom

Sastre S, Carpintero O, Lomas PL (2015) Regional material flow accounting and environmental pressures: the Spanish case. Environ Sci Technol 49(4):2262-2269

Scarpellini S, Aranda A, Aranda J, Llera E, Marco M (2012) R\&D and eco-innovation: opportunities for closer collaboration between universities and companies through technology centers. Clean Technol Environ Policy 14(6):1047-1058

Seppäläa J, Melanen M, Mäenpää I, Koskela S, Tenhunen J, Hiltunen MR (2005) How can the eco-efficiency of a region be measured and monitored? J Ind Ecol 9(4):117-130

Sleeswijk AW (2011) Regional LCA in a global perspective. A basis for spatially differentiated environmental life cycle assessment. Int J Life Cycle Assess 16:106-112

Smol M, Kulczycka J, Henclik A, Gorazda K, Wzorek Z (2015) The possible use of sewage sludge ash (SSA) in the construction industry as a way towards a circular economy. J Clean Prod 95:45-54

Spiers J, Pearson P J, Foxon T (2008) Adapting innovation systems indicators to assess eco-innovation. orca.cf.ac.uk/40682/1/ Foxon_Speirs_Pearson_final.pdf. Accessed 24 Jan 2016

Stahel, W R (2015) The business angle of a circular economy-higher competitiveness, higher resource security and material efficiency. www.slideshare.net/CircularEconomy/article-walter-stahel-oncircular-economy. Accessed 24 Jan 2016

Stahel WR, Reday-Mulvey G (1976) Jobs for tomorrow: the potential for substituting manpower for energy. Vantage Press, New York

Staniškis JK (2012) Sustainable consumption and production: how to make it possible. Clean Technol Environ Policy 14(6):10151022

Staniškis J, Arbačiauskas V, Varžinskas V (2012) Sustainable consumption and production as a system: experience in Lithuania. Clean Technol Environ Policy 14(6):1095-1105 
Thomé AMT, Scavarda A, Ceryno PS, Remmen A (2016) Sustainable new product development: a longitudinal review. Clean Technol Environ Policy. doi:10.1007/s10098-016-1166-3

Towards a Circular Economy (2015) Business Rationale for an Accelerated Transition, www.ellenmacarthurfoundation.org/ assets/downloads/TCE_Ellen-MacArthur-Foundation_9-Dec-2015. pdf. Accessed 20 Jan 2016

Towards the Circular Economy (2012) Economic and business rationale for a circular economy, Cowes: Ellen Macarthur Foundation, www.ellenmacarthurfoundation.org/assets/downloads/ publications/Ellen-MacArthur-Foundation-Towards-the-CircularEconomy-vol.1.pdf. Accessed 20 Jan 2016

Towards the Circular Economy (2013) Opportunities for the consumer goods sector, Cowes: Ellen Macarthur Foundation, www.ellenmacarthurfoundation.org/assets/downloads/publications/ TCE_Report-2013.pdf. Accessed 20 Jan 2016

Towards the Circular Economy (2014) Accelerating the scale-up across global supply chains, Cowes: Ellen Macarthur Foundation, www.ellenmacarthurfoundation.org/assets/downloads/publi cations/Towards-the-circular-economy-volume-3.pdf. Accessed 20 Jan 2016
Urbaniec M, Gerstlberger W (2011) Innovation in environmentoriented networks: influence factors from case study and survey research. Manag Environ Qual Int J 22(6):686-704

Valipour M (2015a) A comprehensive study on irrigation management in Asia and Oceania. Arch Agron Soil Sci 61(9):12471271

Valipour M (2015b) Future of agricultural water management in Africa. Arch Agron Soil Sci 61(7):907-927

Valipour M, Sefidkouhi MAG, Eslamian S (2015) Surface irrigation simulation models: a review. Int J Hydrol Sci Technol 5(1): $51-70$

Varbanov PS, Seferlis P (2014) Process innovation through Integration approaches at multiple scales: a perspective. Clean Technol Environ Policy 16(7):1229-1234

Wdowin M, Franus M, Panek R, Badura L, Franus W (2014) The conversion technology of fly ash into zeolites. Clean Technol Environ Policy 16(6):1217-1223

Xu J, Deng Y, Yao L (2014) Sustainable development-oriented industrial restructuring modeling and analysis: a case study in Leshan. Clean Technol Environ Policy 16(2):267-279 